\title{
The Commercial Paper Market, the Fed, and the 2007-2009 Financial Crisis
}

\author{
Richard G. Anderson and Charles S. Gascon
}

\begin{abstract}
Since its inception in the early nineteenth century, the U.S. commercial paper market has grown to become a key source of short-term funding for major businesses, with issuance averaging over $\$ 100$ billion per day. In the fall of 2008, the commercial paper market achieved national prominence when increasing market stress caused some to fear that, given its size and importance, the market's failure would sharply worsen the recession. The Department of the Treasury and Federal Reserve enacted programs targeted at providing credit and liquidity to restore investor confidence. The authors review the history of the commercial paper market, describe its structure and key relationships to money market mutual funds, and present a detailed discussion of the crisis in the market, including the resulting Federal Reserve programs. (JEL G01, G24, E52)
\end{abstract}

Federal Reserve Bank of St. Louis Review, November/December 2009, 91(6), pp. 589-612.

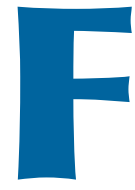

or both small and large American businesses, commercial paper (CP) issuance is an important-and often lower-costalternative to bank loans as a means of short-term financing. Paper is sold in different forms: Some paper is sold unsecured (that is, without specific collateral), while other paper is secured by bank-issued letters of credit or pools of assets, including a firm's receivables. The funds raised through CP issuance have a variety of uses, including payroll and inventory finance.

$\mathrm{CP}$ is important for investors as well. Larger investors, including institutions, directly purchase CP as a short-term, low-risk investment. For smaller investors, money market mutual funds (MMMFs) intermediate between largerdenomination CP and the liquid, smallerdenomination shares that they issue to the public. ${ }^{1}$

Since the inception of the CP market in the early nineteenth century, it has grown such that today CP issuance exceeds that of Treasury bills.
The early years of the CP market were dominated by issuers in the nonfinancial sectors of the economy, including transportation and utility companies, who borrowed by issuing CP to wealthy individuals, other businesses, and financial institutions. By the twentieth century, as the demand for durable goods rose and consumers began purchasing items on credit, the CP market became dominated by financial issuers. The rise of MMMFs during the 1970s boosted the growth of CP by (indirectly) allowing small investors access to CP investments. During the 1980s, the CP market began to develop into its current form, particularly with the creation of the asset-backed commercial paper (ABCP) conduit.

During the autumn of 2008, some feared that stress on-and potential failure of-the CP market

\footnotetext{
1 MMMFs purchase low-risk, large-denomination securities such as commercial paper and government securities, and issue "shares" at $\$ 1$ per share.
}

Richard G. Anderson is a vice president and economist at the Federal Reserve Bank of St. Louis and a visiting scholar at the School of Business, Aston University, Birmingham, United Kingdom. Charles S. Gascon is a senior research associate at the Federal Reserve Bank of St. Louis. The authors thank Standard \& Poor's Financial Services LLC, Moody's Investors Service, and Fitch Ratings for their assistance in the preparation of this article and permission to cite their reports. Special thanks is extended to Everett Rutan for his comments on earlier versions.

(C) 2009, The Federal Reserve Bank of St. Louis. The views expressed in this article are those of the author(s) and do not necessarily reflect the views of the Federal Reserve System, the Board of Governors, or the regional Federal Reserve Banks. Articles may be reprinted, reproduced, published, distributed, displayed, and transmitted in their entirety if copyright notice, author name(s), and full citation are included. Abstracts, synopses, and other derivative works may be made only with prior written permission of the Federal Reserve Bank of St. Louis. 


\section{Figure 1}

\section{Commercial Paper Issuance by Maturity, 2008 (average, \$ billions)}

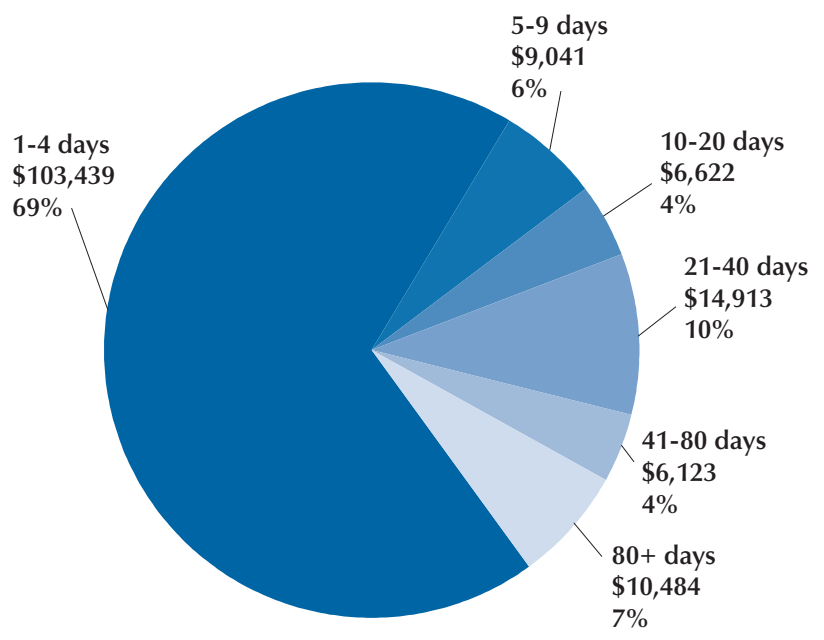

SOURCE: Federal Reserve Board, Volume Statistics for Commercial Paper Issuance.

might sharply worsen the recession. In response, the Treasury and Federal Reserve enacted programs to restore stability. These programs focused on enhancing market liquidity, not on removing default risk from the market.

\section{THE STRUCTURE OF THE COMMERCIAL PAPER MARKET}

In its traditional form, CP is an unsecured promissory note issued by a business (either financial or nonfinancial) for a specific dollar amount and with maturity on a specific date. ${ }^{2}$ Companies issue $\mathrm{CP}$ as a low-cost alternative to bank loans, as it is exempt from Securities and Exchange Commission (SEC) registration. ${ }^{3} \mathrm{CP}$ is generally

\footnotetext{
2 The exception being ABCP, which is CP with specific assets attached as collateral. We discuss this type of CP in more detail below.

3 CP is exempt from SEC registration if the following three criteria are met: (i) the maturity of the paper is less than 270 days, (ii) notes must be of a type not ordinarily purchased by the general public, and (iii) issues must be used to finance "current transactions" (Hahn, 1998).
}

issued in large denominations of $(\$ 100,000$ or more). The maturity on CP averages 30 days but may range up to 270 days. Proceeds from CP issuance are used to finance "current transactions," including meeting payroll obligations, and funding current assets, such as managing receivables or inventories. Figure 1 displays the maturity composition of CP issued in 2008; that year, the majority of CP had a maturity of less than 1 week.

Similar to Treasury bills, CP is typically issued at a discount, meaning that the buyer pays less than face value and receives face value at maturity: The "interest" is equal to the face value minus the purchase price. Although CP is issued at short maturities to minimize interest expense, many issuers roll over CP by selling new paper to pay off maturing paper. Because of modest credit risk, yields on CP are slightly higher than on Treasury bills of similar maturity. Large denominations and short maturities typically limit the CP market to large institutional investors, such as MMMFs.

CP generally is classified in three broad (but overlapping) categories: nonfinancial, financial, and asset-backed. Further, CP may be classified as being sold with the assistance of a CP dealer (dealer placed) or without (directly placed). Traditional nonfinancial and financial paper, respectively, are unsecured short-term debt issued by highly rated corporations, including industrial firms, public utilities, bank holding companies, and consumer finance corporations. ABCP, on the other hand, is more complicated. The simplest description of ABCP is as a form of securitization: As the name implies, it is CP with specific assets attached. In financial industry jargon, ABCP is issued by "conduits." Conduits are structured to be bankruptcy remote and limited in purpose. ${ }^{4}$ Each conduit includes a special-purpose vehicle (SPV) that is the legal entity at the center of the program and a financial adviser (usually a commercial or investment bank) that manages the program and determines the assets to be purchased

\footnotetext{
4 Bankruptcy remote refers to all participants in a conduit agreeing not to force the SPV into bankruptcy prior to a year and a day after issuance of the conduit's most recent CP; this ensures redemption of all CP. Limited purpose refers to issuance of CP as its sole business.
} 
Table 1

Asset Composition of Multiseller Conduits (approx.)

\begin{tabular}{lrrrr} 
& $\mathbf{2 0 0 2}$ & $\mathbf{2 0 0 6}$ & $\mathbf{2 0 0 7}$ & $\mathbf{2 0 0 8}$ \\
\hline Consumer Assets & & & 44.4 & 45.9 \\
Credit Card Receivables & 41.9 & 44.2 & 16.0 & 17.8 \\
Auto Loans and Leases & 12.3 & 13.8 & 13.1 & 12.7 \\
Credit Cards & 14.9 & 10.5 & 7.2 & 8.5 \\
Student Loans & 1.0 & 4.2 & 4.8 & 4.4 \\
Residential Mortgages & 8.2 & 11.3 & 3.1 & 2.4 \\
Other Consumer & 5.5 & 4.3 & 54.8 & 44.0 \\
Commercial Assets & 51.5 & 43.3 & 13.9 & 14.0 \\
Trade Receivables & 14.6 & 15.4 & 13.6 & 12.9 \\
Commercial Loans and Leases & 6.6 & 12.4 & 3.6 & 4.1 \\
Equipment Loans and Leases & 10.6 & 3.4 & 14.7 & 13.0 \\
Other Commercial & 19.6 & 12.1 & 9.7 & 10.1 \\
Securities & 6.6 & 12.5 & 100 &
\end{tabular}

SOURCE: Moody's ABCP Query: Data are the share of total outstanding as of year-end.

and the ABCP paper to be issued. The owner of the conduit receives nominal dividend payments; and because the SPV does not generally have any employees, fees are paid to an administrator (normally a bank) to manage the flow of CP and funds.

To investors, ABCP programs are less transparent than traditional unsecured corporate $\mathrm{CP}$ the SPV is an opaque entity that holds assets that are unknown to the purchaser of the ABCP. Performance of the ABCP depends on the skill of the bank adviser, which essentially is saying to ABCP purchasers: "Trust us with your funds and we will invest them for you." The degree of disclosure in the market varies widely. Some multiseller ${ }^{5}$ conduits provide investors with at least a list of assets, liquidity enhancements, and performance history, whereas other more-complex conduits provide very limited disclosure. During normal times, yields on ABCP have been approximately 75 basis points greater than yields on traditional unsecured

${ }^{5}$ A bank-sponsored multiseller conduit backs its CP with a diverse pool of assets, as opposed to a single-seller conduit (e.g., a conduit sponsored by General Motors Acceptance Corporation), which backs its CP with pools of specific assets (e.g., auto loans).
CP. ${ }^{6}$ This spread is a continued mystery with numerous explanations: Why should CP with assets attached as collateral pay a higher yield than CP with no such collateral? Some have suggested this spread exists because ABCP is (indirectly) being issued by firms unable to directly issue their own CP. However, this does not explain why ABCP issued by a conduit sponsored (and insured) by a bank would have a higher yield than CP directly issued by the same bank lacking any collateral. Moody's (2009) attributes the yield premium specifically to the lack of transparency, noting that traditional CP is relatively easily understood, while ABCP is issued by an unfamiliar SPV with assets from anonymous sellers.

Because of its role in the 2008 credit crisis, some additional discussion of ABCP is valuable. $\mathrm{CP}$ conduits, in their structure, are classic financial intermediaries: They purchase one or more types of financial assets and issue ABCP in their

6 This spread can be calculated using rates on AA-rated CP reported in the Federal Reserve Board volume statistics on CP issuance. The spread changes depending on the issue type (financial or nonfinancial) and maturity chosen. 


\section{Figure 2}

\section{ABCP Conduits-Banking Without a Bank}

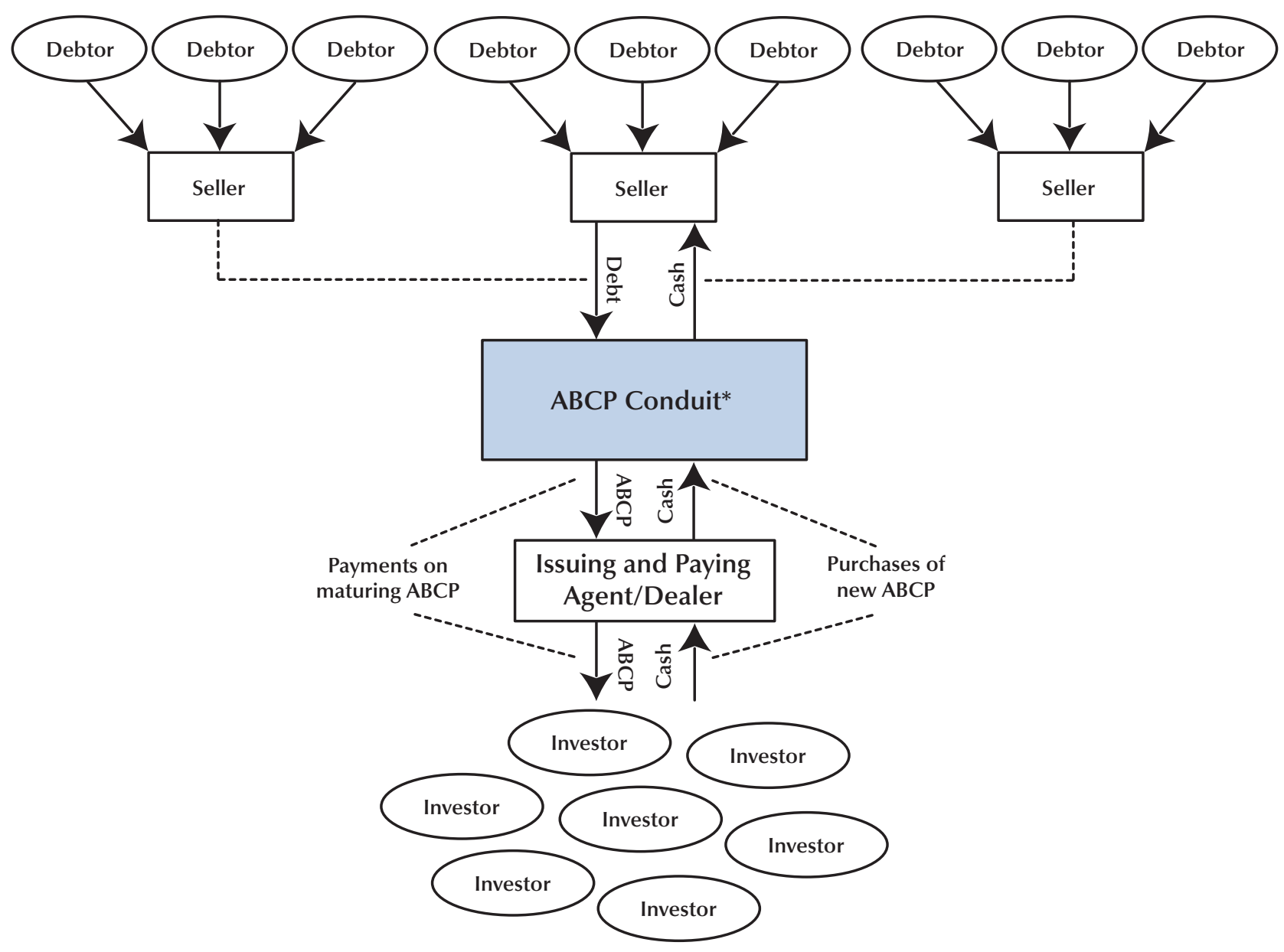

NOTE: *See Figure 3 for additional details.

own name. Their business purpose is to arbitrage risk and rate spreads between the assets they purchase and the liabilities they issue. ABCP conduits come in many types. The largest type is multiseller conduits. The major cost to a multiseller ABCP conduit is the insurance of risk. To insure risk, conduits pay fees to a liquidity provider (rollover risk) and a credit-enhancement provider (default risk).

ABCP issued by multiseller conduits is often used to finance the purchase of consumer and commercial assets (Table 1). A firm that sells receivables to a conduit frees its own funds and reduces its need to borrow. Large, creditworthy firms typically sell their paper directly to investors via an agent or dealer, a practice referred to as a "single-seller conduit." Smaller firms, however, find this method costly, and prefer to operate via a multiseller ABCP conduit in which the firm sells its debts to a bank-advised SPV which, in turn, sells ABCP to investors. Large firms may also use multiseller ABCP conduits as an additional source of liquidity in cases when they have a quick turnaround on trade receivables that are not large enough to warrant "traditional" CP issuance.

Unrated firms may also lower borrowing costs 


\section{Figure 3}

\section{Typical ABCP Conduit}

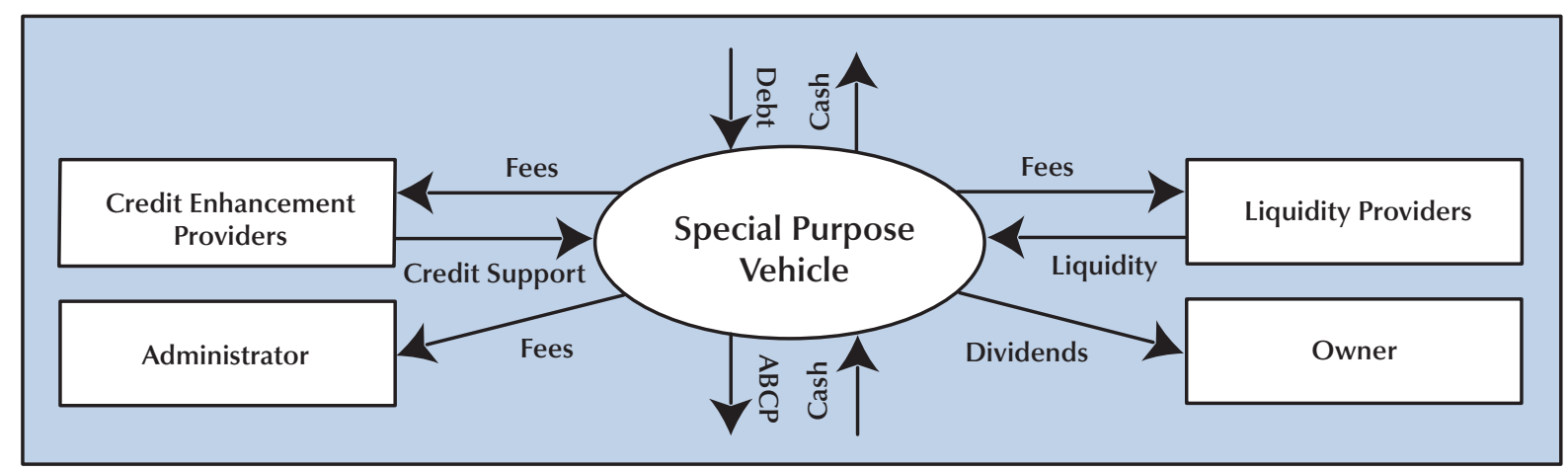

SOURCE: Adapted from Moody's (2003).

via multiseller conduits by paying a spread to the conduit sponsor.

Figures 2 and 3 outline the securitization of assets through a multiseller ABCP conduit. At the top of the diagram are debtors (i.e., individuals or businesses) who borrow money from sellers (i.e., mortgage lenders or banks). In the center of Figure 2 is the ABCP conduit; its SPV is illustrated in Figure 3. The ABCP SPV purchases, from the sellers, the debt at some price less than face value. This overcollateralization (or "haircut") provides an equity cushion to CP investors. Because finding suitable investors may be costly, the ABCP SPV has a relationship with a dealer (i.e., an investment bank), who suggests a price and finds suitable investors.

Because the maturity on the CP is shorter than the maturity on the original loans, the ABCP conduit will roll over the maturing CP to pay investors. As with any CP program, rating agencies require $\mathrm{ABCP}$ conduits to obtain liquidity backstops on each transaction to assume much of the rollover risk. Liquidity providers will normally provide funds on non-defaulted assets. Because there is always a risk that some debtors fail to make payments, investors require additional program-wide credit enhancements, generally in the form of a bank letter of credit or insurance company surety bond on some fraction of the maximum program size. ${ }^{7}$ Normally, these agreements require payment by the provider once other sources of funds have been exhausted. In many cases the administrator is the same bank providing the liquidity and credit enhancements. As a result, the credit rating of the conduit is closely related to the credit rating of liquidity and credit providers, as well as the reputation of the managing party.

Table 2 shows the composition of CP outstanding by issuer and placement type. The top two rows report the average amount outstanding in 2001 and 2008, and the bottom two rows report shares as a percentage of the total. For each issuer, the average amount outstanding is disaggregated by the placement type. For example, during 2001, financial CP outstanding averaged $\$ 617.0$ billion (41.4 percent of the total), of which $\$ 336.5$ billion was placed by dealers (22.6 percent of the total) and $\$ 280.6$ billion was directly placed (18.8 percent of total). On average, 90 percent of outstanding CP was either ABCP or financial CP in 2008.

A firm ordinarily requires a dealer to place its paper if it lacks the name recognition necessary

\footnotetext{
7 This really applies only to bank-sponsored multiseller programs. Securities arbitrage programs have recently added letters of credit, while structured investment vehicles use overcollateralization or sell subordinate notes. Single-seller conduits tend to use overcollateralization.
} 
Table 2

Commercial Paper Outstanding by Issuer and Placement

\begin{tabular}{|c|c|c|c|c|c|c|c|c|c|c|}
\hline & \multicolumn{3}{|c|}{ Financial } & \multicolumn{3}{|c|}{ Nonfinancial } & \multicolumn{3}{|c|}{ Asset-backed } & \multirow{2}{*}{$\frac{\text { All types }}{\text { Total }}$} \\
\hline & Dealer & Directly & Total & Dealer & Directly & Total & Dealer & Directly & Total & \\
\hline \multicolumn{11}{|c|}{ Total (average), $\$$ billions } \\
\hline 2001 & 336.5 & 280.6 & 617.0 & 205.9 & 38.5 & 244.4 & 500.8 & 127.6 & 628.4 & 1489.8 \\
\hline 2008 & 552.2 & 231.5 & 783.7 & 174.6 & 17.1 & 191.7 & 663.1 & 100.4 & 763.6 & 1739.3 \\
\hline \multicolumn{11}{|c|}{ Share (percent) } \\
\hline 2006 & 22.6 & 18.8 & 41.4 & 13.8 & 2.6 & 16.4 & 33.6 & 8.6 & 42.2 & 100.0 \\
\hline 2008 & 31.7 & 13.3 & 45.1 & 10.0 & 1.0 & 11.0 & 38.1 & 5.8 & 43.9 & 100.0 \\
\hline
\end{tabular}

SOURCE: Federal Reserve Board, Volume Statistics for Commercial Paper Issuance.

to attract investors or if its funding requirements either are too limited or infrequent to warrant building its own distribution system. Direct issuers of CP, most of them traditional issuers, borrow in sufficient size and frequency that the costs of developing an in-house distribution system are less than the costs of placing paper through a dealer. For nonbanks, an in-house system may become profitable if CP issuance reaches $\$ 500$ million or more. Mostly the major finance companies and large banking organizations that also distribute wholesale liabilities (such as certificates of deposit [CDs]) place their paper directly. Only a few nonfinancial firms are direct issuers of paper.

Many companies build close relationships with their dealers: If a company is willing to sell its paper at the dealer's suggested price, the dealer will agree to purchase unsold paper. Yet, relationships with dealers may be problematic and are not explicitly guaranteed. Market intelligence suggests that dealer relationships for multiseller conduits were "strained to the breaking point" during the fall of 2007, and "collapsed" for many singleseller and securities arbitrage conduits. Generally, according to dealer reports in Stigum and Crezcenzi (2007), "competition among dealers is fierce...at a 70 percent utilization rate you maybe break even or are losing a bit of money...[at a] 90 percent utilization rate you begin to make real profits." Dealers charge clients a fee that is less than oneeighth of 1 percentage point, which in 2008, translated into roughly $\$ 150$ million in daily fees on $\$ 120$ billion of CP issued daily. ${ }^{8}$

\section{THE DEVELOPMENT OF THE COMMERCIAL PAPER MARKET}

In the early years of the CP market, the nineteenth century, nonfinancial firms (including textile mills and railroad companies) were the major issuers of paper. By the early twentieth century, particularly following the founding of General Motors Acceptance Corporation (GMAC) in 1919, the CP market expanded to include financial paper. After World War II, increased sales of durable goods on credit (especially televisions and automobiles) encouraged expansion of consumer finance companies and, in turn, the CP market (Stigum and Crezcenzi, 2007, Chap 3). Later, even for business purposes such as financing inventory and raising cash for current operating expenses, CP increasingly replaced bankers' acceptances as the instrument of choice for shortterm financing.

Figure 4 shows the trend in the amount of CP outstanding (all issue types) since 1952. Prior to 2000, the CP market grew steadily as both borrow-

\footnotetext{
${ }^{8}$ Data on daily issuance of dealer paper are not available; the calculation assumes 80 percent (the percentage of total outstanding issued by dealers) of the average daily issuance is placed by dealers. The dealer fee of 0.0125 percent is from Stigum and Crezcenzi (2007, p. 989).
} 


\section{Figure 4}

\section{Quarterly Commercial Paper Outstanding (1952-1986 and 1987-2009)}
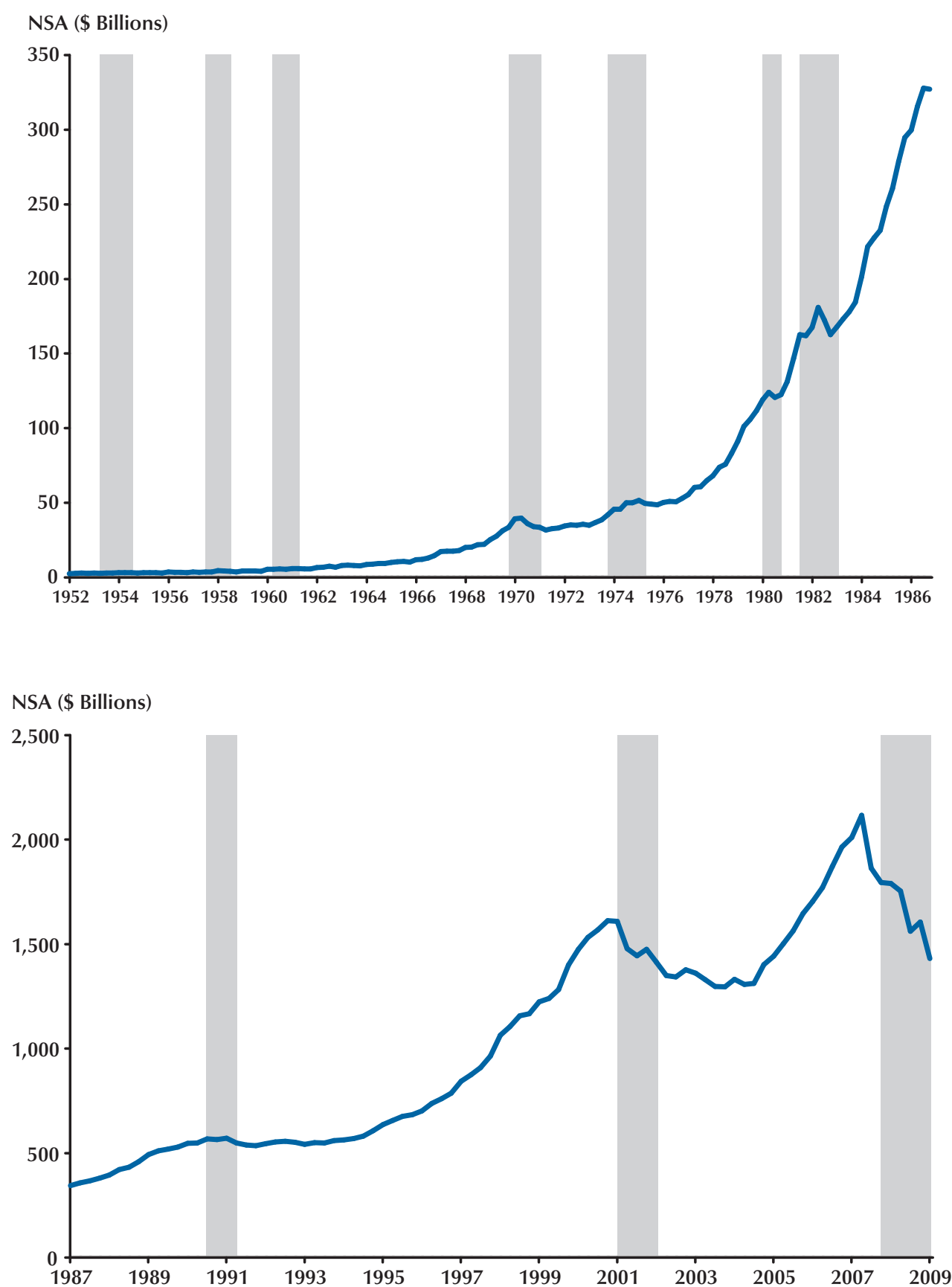

SOURCE: Federal Reserve Board, Flow of Funds, Table L.208. 
Table 3

Major Holders of Commercial Paper*

\begin{tabular}{|c|c|c|c|c|c|}
\hline & \multicolumn{4}{|c|}{ Percent } & \multirow{2}{*}{$\begin{array}{c}\text { \$ Billions } \\
2008\end{array}$} \\
\hline & 1952-1971 & $1972-1991$ & 1992-present & 2008 & \\
\hline Money Market Mutual Funds & - & 18.2 & 34.7 & 38.5 & 615.6 \\
\hline Funding Corporations & 3.3 & 11.5 & 12.9 & 23.0 & 367.5 \\
\hline Foreign Sector & 15.6 & 4.6 & 9.5 & 14.6 & 233.2 \\
\hline State \& Local Governments & - & - & 8.1 & 7.7 & 123.8 \\
\hline Security Brokers \& Dealers & - & 4.7 & 3.0 & 4.1 & 65.7 \\
\hline Mutual Funds & 3.3 & 2.6 & 5.7 & 3.3 & 52.0 \\
\hline Life Insurance Companies & 2.2 & 7.5 & 5.2 & 2.7 & 42.8 \\
\hline Private Pension Funds & - & 8.2 & 2.8 & 2.3 & 36.9 \\
\hline State \& Local Gov. Retirement Funds & - & 0.8 & 3.2 & 2.0 & 31.9 \\
\hline Commercial Banking & 18.4 & 7.5 & 0.4 & 0.9 & 15.0 \\
\hline Nonprofit Organizations & 42.7 & 23.3 & 8.2 & 0.7 & 10.4 \\
\hline Nonfarm Nonfinancial Corporate Business & 14.0 & 9.0 & 4.0 & 0.3 & 4.7 \\
\hline Monetary Authority & 0.5 & - & - & - & 0.0 \\
\hline Savings Institutions & - & 1.2 & - & - & - \\
\hline Credit Unions & - & 0.1 & 0.1 & - & - \\
\hline GSEs & - & 0.6 & 2.1 & - & - \\
\hline Total (percent) & 100.0 & 99.7 & 100.0 & 100.0 & \\
\hline Total (\$ billions) & 13.3 & 262.9 & $1,234.4$ & $1,599.5$ & $1,599.5$ \\
\hline
\end{tabular}

NOTE: *Data reported are for open market paper, which contains both CP and bankers acceptances. CP comprises 85 percent of open market paper over the sample and 99 percent since 1998.

SOURCE: Federal Reserve Board, Flow of Funds, Table L.208.

ers and investors shifted into CP from alternative money market instruments, including Treasury bills, bankers' acceptances, and CDs. ${ }^{9}$ The downturn that took place in the 2000 is discussed further below. In 1970, CP comprised only one-quarter of the dollar volume of outstanding money market instruments; in 2006, it comprised two-thirds (Stigum and Crezcenzi, 2007, p. 967).

The introduction of MMMFs in 1971 had a large and long-lasting impact on the CP market. Fueled initially by rising demand for consumer durables, growth of the CP market was ignited in the 1970s by widespread investor enthusiasm for MMMFs. For savers and investors, MMMF

9 See Anderson (2009a,b) for a discussion of bankers' acceptances. Today, the bankers' acceptance market is moribund, overtaken by CP. shares were an attractive alternative to bank deposits; for corporate borrowers, CP was an attractive alternative to bank loans. Assets of MMMFs increased sixfold between 1980 and the end of 1991 (Table 3). During the period spanning 1972-92, MMMFs on average held 18.2 percent of all outstanding CP; in 2008, it was almost 40 percent. The increase in MMMF holdings was not steady: During three years (1978-81), the share of CP held by MMMFs soared to 32 percent from less than 1 percent, subsequently remaining near 30 percent. At year-end 1991, the MMMF industry held about one-third of all CP outstanding and was the largest single investor. Holdings of CP by foreign investors, on the other hand, have increased gradually since the early 1990s. (In Table 3, the share held by funding corporations 


\section{Figure 5}

\section{Monthly Commercial Paper Outstanding (1953-1974)}

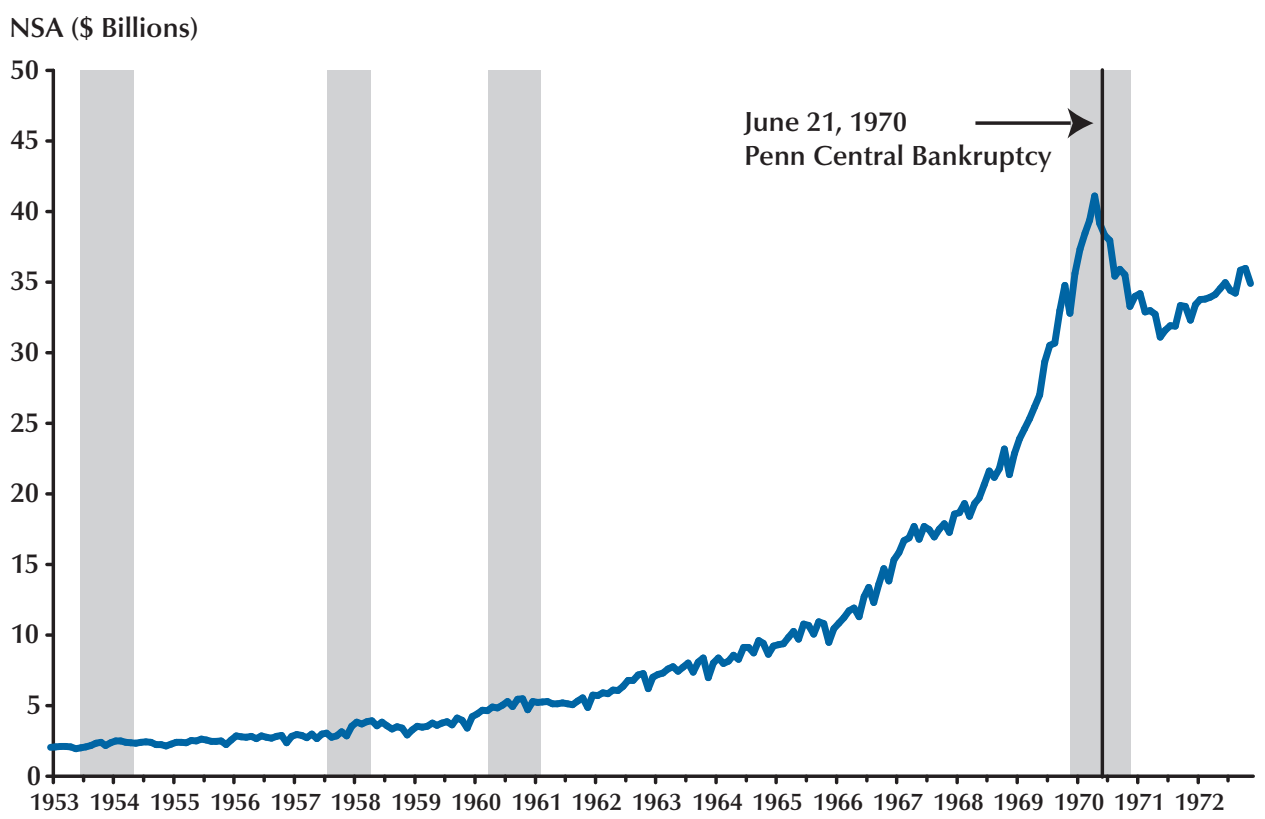

SOURCE: Board of Governors (1976) and Federal Reserve Board, Commercial Paper Statistics.

is the residual, holdings not accounted for by the other categories. $)^{10}$

\section{Problems in the Early Years: The Penn Central Collapse}

Penn Central railroad was a major issuer of CP, with approximately $\$ 84$ million outstanding in the summer of 1970. As the company's cash flows dwindled, debt holders pushed for government assistance that would have allowed Penn Central to repay maturing CP. The assistance plan failed, and on June 21, 1970, Penn Central filed for bankruptcy (Calomiris, 1994). The bankruptcy of Penn Central rattled the CP market. The econ-

\footnotetext{
${ }^{10}$ Funding corporations consist of four types of financial institutions and entities: (i) subsidiaries of foreign banks that raise funds in U.S. markets and transfer proceeds to foreign banking offices in the United States; (ii) subsidiaries of foreign banks and nonbank financial firms that raise funds in the United States and transfer them to a parent company abroad; (iii) nonbank financial holding companies; and (iv) custodial accounts for reinvested collateral associated with securities-lending operations.
}

omy was already in recession, and the financial health of the company had apparently deteriorated in a matter of months. Market participants became worried that other highly rated CP issuers could be in a similar position.

In the years before the collapse, the CP market had experienced rapid growth and appeared to be isolated from economic downturns. Figure 5 indicates that total CP outstanding did not decline during either of the prior recessions. Because the market had not previously experienced such stress, lenders were uncertain of potential spillover effects of the bankruptcy, including the inability to roll over existing paper at maturity. The unwillingness of the Congress and the Federal Reserve to ensure payment of Penn Central's debt left creditors facing substantial losses. In response to the crisis, the Fed encouraged member banks to borrow at the discount window and make loans to $\mathrm{CP}$ issuers. ${ }^{11}$ According to reports at the time,

${ }^{11}$ See Calmoris (1994) for additional details. 
discount window borrowing to finance CP rollovers reached $\$ 500$ million in the weeks following the collapse. The actions of the Fed assured financial markets that the liquidity needed to meet obligations would be available. Nevertheless, outstanding CP declined by 21 percent during subsequent quarters before turning upward in the second quarter of 1972. Eventually, the market regained its confidence-CP grew steadily for the next three decades. However, after the crisis CP issuers were more reserved and began securing lines of credit in case of market disruptions.

\section{The Adolescence of the U.S. Commercial Paper Market: 1980-199212}

The U.S. CP market matured during the 1980s. At the beginning of the decade, issuance was primarily by a small number of large, prominent, and creditworthy companies. During the decade, everything changed. The market's size grew fivefold. New issuers and dealers arrived, while some older issuers disappeared. New forms of paper were introduced, most importantly ABCP.

In the 1980s, corporate borrowers faced paying relatively high rates (compared with historical experience) on both long-term funds (bonds) and bank loans, owing in part to robust economic growth. A less costly alternative was issuance of $\mathrm{CP}$, which grew rapidly. Many new issuers were attracted to the market, including smaller U.S. corporations, foreign corporations, and foreign financial institutions. The development of a market in currency swaps allowed foreign borrowers to combine U.S. dollar-denominated CP issuance with swaps so as to create liabilities in other currencies. ABCP also came into general use, providing off-balance-sheet financing for trade and credit card receivables. Finally, the growth of MMMFs, coupled with a shift in the composition of their investments toward CP, made them the largest single source of funds to the market (see Table 3).

A series of defaults on CP that began in 1989 caused tighter regulations to be imposed on MMMF holdings of medium-grade paper. Heightened investor concerns effectively forced many medium-

12 This section is based on Post (1992). quality issuers to cut back sharply on their use of the CP market. Increasing costs also changed the role of banks in the CP market. Financial stress at banks became manifest in the pressure from markets and regulators to increase their capital levels, which in turn increased their costs of providing letters of credit and backup liquidity to the CP market. Partially offsetting this effect, in terms of overall CP market volume, were efforts of banks to increase loan rates and margins on loans. Growth of the CP market was neither smooth nor painless. The composition of firms issuing CP changed as defaults reduced investor appetite for medium-grade paper. At times, issuers returned to banks, finding bank loans less expensive than CP.

Defaults of CP are rare. Between 1971 and mid-1989, no defaults occurred in U.S. CP except for the litigation-driven default by Manville Corporation in 1982 (Post, 1992, p. 888). In mid1989, the U.S. CP market was hit with three defaults; four more followed in 1990. Because fund advisers injected capital to cover the shortfalls, investors incurred no losses. The SEC subsequently tightened Rule 2a-7 to generally require two ratings on CP held by money funds and to limit a fund's holdings of a single firm's paper (p. 889). Growth of the paper market slowed thereafter, and some medium-grade issuers found borrowing at banks less expensive. ${ }^{13}$

The financial markets calmed after 1990 and were capable of handling the funding needs of medium-grade firms. Medium-grade issuers successfully tapped bank lines of credit or their CP dealers, while ABCP absorbed some of the needs of these firms and grew rapidly. But investors remained wary of medium-grade paper. Interest rates on it spiked again both at midyear and at year-end 1991 because many investors did not want to show such holdings on their published financial statements. The June 1991 default of Columbia Gas, a secondtier issuer, renewed concerns about the safety of medium-grade paper (p. 889).

\footnotetext{
${ }^{13}$ New Basel Accord risk-based capital guidelines for banks, adopted in 1988, would become effective at year-end, and market participants grew increasingly uncertain about the capacity of banks to honor all their loan commitments. As a result, rates paid on CP, even by highly rated firms, jumped in December 1990. This proved, however, to be the point of maximum stress.
} 
Issuers at the end of the 1980s differed greatly from those at the beginning. At the end of 1989, about 1,250 corporations and other entities had paper programs in the U.S. CP market, 500 more than in 1980. Many new issuers were foreign firms and smaller, lesser-known U.S. firms; previously, CP issuers almost uniformly were large, wellknown U.S. corporations.

The Growth in Dealer-Placed Financial Paper. Throughout the life of the CP market, methods of issuance have continued to evolve. During the 1980s, direct issuers expanded rapidly. Early in the decade, approximately 60 percent of all CP was sold directly by issuers to investors (p. 883). Among the more important issuers were large finance companies; these grew rapidly after the Economic Recovery Tax Act of 1981 promoted business use of leasing.

Bank holding companies continued to use the CP market to support parent company operations, including leasing and lending by nonbank subsidiaries. By the end of the decade, outstanding paper placed directly by financial firms surpassed $\$ 200$ billion, more than triple the level at the start of the decade...[Yet, even faster growth was experienced by firms that used dealers for distribution.]...By 1989, dealer-placed paper accounted for 60 percent of all CP outstanding, up sharply from about 40 percent at the start of the decade (p. 883).

In part, the growth was supported by Federal Reserve Board rulings in 1986 and 1987 that authorized certain so-called Section 20 subsidiaries of bank holding companies to deal in CP to a limited extent; by year-end 1991, these subsidiaries accounted for about 14 percent of outstanding dealer-placed paper. And by December 1990, dealer-placed financial CP outstanding surpassed the amount of directly placed financial CP (p. 884).

The increased share of dealer-placed paper also reflected, in part, the changing composition of issuers: Dealers were required for the aggressive marketing needed to package and sell new issuers and new types of CP programs.

During the mid- to late 1980s, the presence of foreign financial institutions in the U.S. market grew, and these firms generally required dealer assistance to promote their names to U.S. investors. By year-end 1991, these firms had outstanding CP in excess of $\$ 110$ billion, slightly more than half of all dealer-placed financial paper. Highly rated foreign banks (or their U.S. subsidiaries) accounted for 55 percent of this paper (pp. 884-85).

The Growth in Guaranteed Paper. The growth in guaranteed paper is described by Post (p. 884).

The share of CP programs that were fully (100 percent) enhanced by credit guarantees-often bank letters of credit-from highly rated third parties grew dramatically in the first half of the decade. In fact, programs with such credit enhancements accounted for about all the net increase in the number of CP issuers rated by Moody's over that period. Presumably, most of these programs were small because their outstanding CP accounted for less than 10 percent of all outstanding paper.

Because investors in such paper rely on the guarantor, rather than the issuer, to make payment in full upon maturity of the paper, the paper carries the rating of the guarantor. Whereas traditional issuers entered the market on the strength of their own credit quality (or that of their parent), many of the new CP programs of the first half of the 1980s gained access to the market on the strength of guarantees by unrelated entities.

Introduction of the Asset-Backed Commercial Paper Conduit. The decade's second innovation, and perhaps its most important, was the introduction of the bank-advised ABCP conduit in $1983 .{ }^{14}$ The structure of the typical multiseller ABCP conduits was discussed previously. When considered solely by their economic functions, such conduits, essentially, are regarded as "banks without banking charters." The motives at the time of their introduction are well described by Post (1992, p. 886):

The development of the asset-backed sector of the CP market arose from several factors. U.S. banking organizations saw an opportunity to generate fee income from potential participants in their programs-many of

\footnotetext{
${ }^{14}$ See Kavanaugh, Boemio, and Edwards (1992).
} 
which were the same investment-grade firms that they had lost as loan customers to the CP market. These banking organizations also became more familiar with asset securitization. This similarity resulted, in part, from increased market and regulatory pressure to increase their capital ratios. Asset securitization, and asset-backed CP in particular, permitted banks to channel would-be borrowers to funding off of bank balance sheets.

Another factor was that financial markets became increasingly familiar with, and thus more willing to accept, programs that required structuring, such as those with credit guarantees. Dealers saw opportunities to market asset-backed programs to companies seeking to increase liquidity or to reduce leverage, regardless of size or rating. Moreover, they already had proved successful in marketing lower-rated firms to the $\mathrm{CP}$ market via guaranteed programs and realized that a pool of potential business existed in companies that were too small to tap the CP market through their own guaranteed programs. Thus, banking organizations formed bank-advised asset-backed programs, relying on dealers.

ABCP conduits increased in number from 3 in 1985 to 89 by year-end 1991. Between 1990 and 1991, ABCP programs accounted for virtually all the increase in domestic CP issuers. By year-end 1991, ABCP accounted for about 9 percent of all outstanding CP.

In circumstances reminiscent of the 2008 credit crisis, credit problems at sponsoring bank holding companies slowed the growth of ABCP paper during the 1989-92 credit crisis. Cantor and Roriques (1994) report that the perceived credit risk of CP increased as the number of defaults on CP "soared" (p. 171) and the number or downgrades outpaced the number of upgrades between 1988 and 1989 (p. 194). ABCP conduit ratings were downgraded as large loan losses, and the need to raise capital ratios reduced the ratings of sponsoring banks. Outstanding CP of bank holding companies (almost all directly issued) decreased from a peak of $\$ 52$ billion in January 1990 to $\$ 24$ billion at year-end 1991 .

\section{The Maturation of Commercial Paper: 1992 to Fall 2007}

This era of the CP market is characterized by the steady decline in the prominence of nonfinancial $\mathrm{CP}$ and the continued rise in ABCP. According to Moody's (2009), ABCP entered the mainstream of money market instruments during the mid1990s as more institutional investors began to significantly increase their holdings. The ABCP market enlarged in the late 1990s when the commercial bank advisers to ABCP conduits discovered arbitrage opportunities in the securitization of asset-backed securities, residential mortgagebacked securities, and collateralized debt obligations. In general, the arbitrage opportunities arose because the longer-term securities purchased by ABCP conduits carried yields in excess of the London Interbank offering rate (LIBOR), while the conduits could issue short-term (1- to 4-day) ABCP at rates no higher than LIBOR (Standard \& Poor's, 2008). Because the rate differential largely reflects the unhedged term premium and the uncovered rollover funding risk, success of the arbitrage depends on the premium not moving sharply.

The Decline in Nonfinancial Commercial Paper. Interaction between the CP market and other types of finance, driven by changes in respective yields, is illustrated by the decrease in nonfinancial CP outstanding during the 2000 recession. Beginning in 2000, total nonfinancial CP outstanding dropped by almost 50 percent in just over 2 years (Figure 6).

Shen (2003) concludes that "aggressive inventory reduction and the widespread practice of replacing [CP] with longer term corporate bonds have reduced the demand for credit in the [CP] market.” Because nominal rates were relatively low following the 2000 recession, businesses elected to reduce uncertainty about future borrowing costs by reducing holdings of CP and issuing bonds at low interest rates. Subsequent data have supported Shen's view. The share of nonfinancial businesses borrowing through the CP market declined from 5.4 percent between 1995 and 2000 to 2.3 percent between 2001 and 2008. At the same time, the share of nonfinancial borrow- 


\section{Figure 6}

\section{Nonfinancial Commercial Paper Outstanding and Manufacturers' Total Inventories}

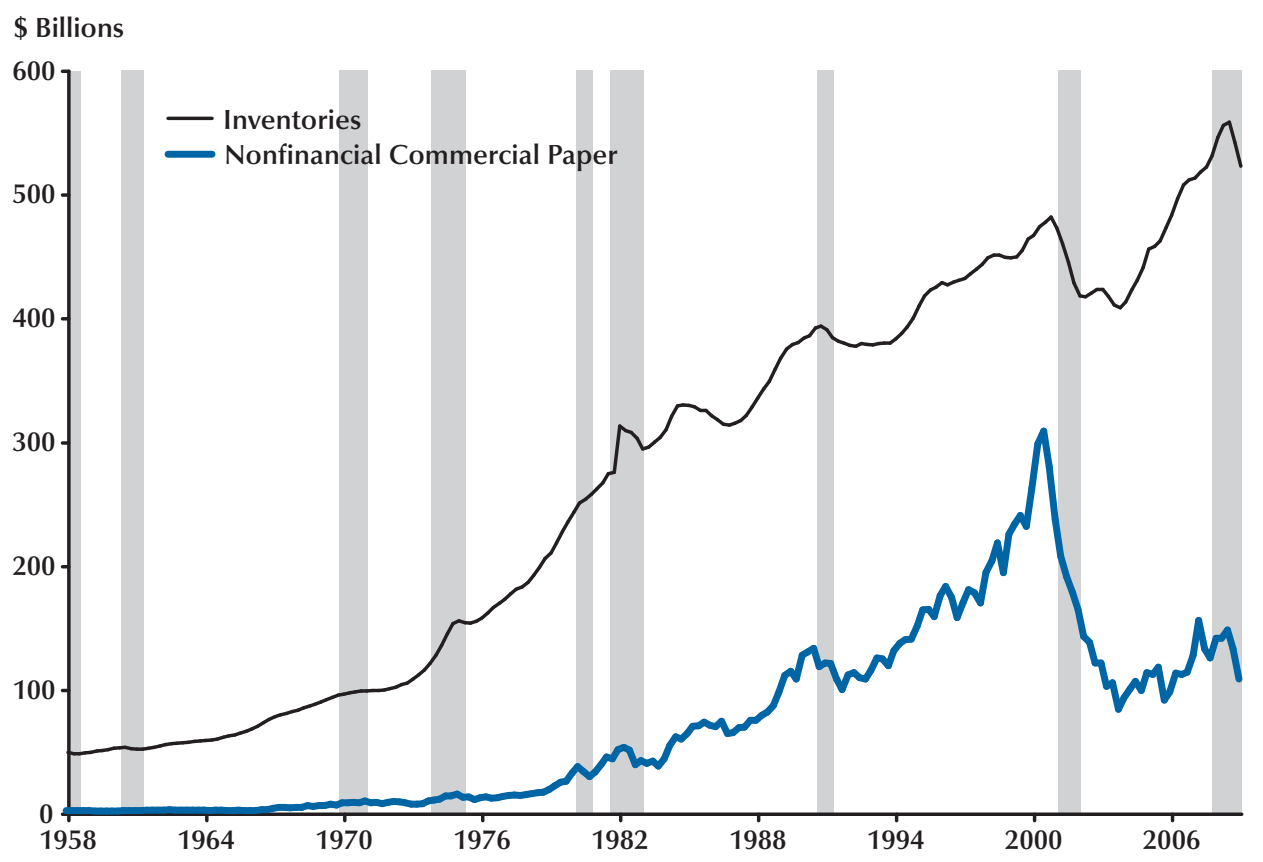

SOURCE: Federal Reserve Board, Census Bureau.

ing through corporate bond issuance increased from 45.9 percent (1995-2000) to 54.4 percent (2001-08). ${ }^{15}$

\section{Innovations in Asset-Backed Commercial} Paper. In 2003, additional innovation changed the internal dynamics of ABCP conduits. Previously, typical conduit programs required three players in supporting roles: the adviser, the liquidity enhancer, and the credit enhancer. At times, one commercial or investment bank would play all three roles but, to avoid self-dealing and conflict of interest, the roles typically were played by two or three separate banks. Seeking to increase profits, some bank advisers brought to market ABCP conduits without liquidity and credit enhancers; instead, the advisers asserted

\footnotetext{
${ }^{15}$ Shares are calculated using data from the Federal Reserve Flow of Funds table L.2; for example, the share of nonfinancial CP borrowing is nonfinancial CP outstanding divided by nonfederal loans outstanding (net municipal loans, mortgages, and consumer credit loans).
}

that the conduit would rely on its own "internal liquidity" to satisfy all obligations (i.e., securities arbitrage ABCP conduits). Maturing $\mathrm{CP}$ that is not rolled over, for example, would be paid off with cash flows generated either from the yields on the assets themselves or by selling the assets (Standard \& Poor's, 2008). ${ }^{16}$ Nationally recognized statistical rating agencies generally accepted the advisers' assertions but required that such conduits maintain a "cushion" between their ABCP outstanding and the market value of the securities they hold. According to Standard \& Poor's (2008)

${ }^{16}$ These conduits are commonly referred to as securities arbitrage ABCP conduits. Generally speaking, the structures of nonbank investment vehicles, such as hedge funds, closely resemble each other although the terminology differs. For hedge funds, the investment manager handles the portfolio choices, and usually is paid based on performance; the administrator handles back-office tasks including issuing and redeeming shares, calculating net asset value, and measuring fund performance; the prime broker or custodian handles clearing and settlement, money lending, and similar investment banking tasks. In some cases, the roles of administrator and investment adviser are performed by the same firm. 
over half of the conduits established between 2004 and 2007 relied, at least in part, on internal liquidity. Acharya, Gale, and Yorulmazer (2009) present a theoretical model of market freezes in which ABCP conduits take a structure very similar to securities arbitrage conduits. The model explains why markets, such as ABCP, that roll over debt can experience sudden freezes.

\section{THE RECENT FINANCIAL CRISIS AND THE COMMERCIAL PAPER MARKET}

Financial crises often are defined by sharp increases in the price of risk - that is, the premium that investors require to purchase investments that they previously bought at a much lower yield. $\mathrm{CP}$ is a financial instrument particularly susceptible to such an increase in risk premiums. What is not clear, however, is the relative importance of investors' willingness to (i) bear risk and (ii) endure a potential decrease in their liquidity. Clearly, both affect CP market difficulties to some degree. Holders of unsecured traditional CP may suffer significant losses if the issuer fails; in recession, the profit outlooks for most firms dim. In addition, most issuers repay maturing paper by rolling it over; if paper cannot be rolled over and if the issuers' banks do not extend credit to pay the holders, repayment to the holders may be delayed for a considerable period. Layered on top was an increased fear that financial assets, except for U.S. Treasuries, could not be resold to other investors.

The CP market achieved national prominence in the fall of 2008. Heightened financial market uncertainty followed the failure of Lehman Brothers on September 15. Investors and lenders, uncertain of both the creditworthiness of counterparties and their own ability to borrow in the future (if necessary), shortened commitments and shifted away from CP-based products toward default risk-free assets, including MMMFs invested solely in U.S. Treasuries. Borrowers argued that a near closure of the market would sharply worsen the recession. Suddenly, the term "shadow banking system" came into common usage. ${ }^{17}$

\section{Market Events: 2007 and 2008}

Difficulties in the CP market were apparent during the fall of 2007. Issuance of ABCP, heavily used by mortgage originators to bridge the financing gap between origination and securitization, began to plummet. Mortgage lenders had backed their paper with pools of home loans awaiting securitization. Write-downs on mortgage-related assets caused investors in ABCP to become wary of the underlying assets. A small portion of ABCP issuers (roughly 10 percent) exercised the option allowing them to extend the maturity of their borrowings, thereby cramming longer maturities down to investors expecting repayment (SahnBubna, 2007). In addition, as the market value of residential mortgage-backed securities fell, ABCP conduits relying on internal liquidity began to fail "cushion tests." In some cases, conduits were forced to sell securities-but into a fearful secondary market with few buyers. Between August 6 and 14, 2007, four conduits (representing 1.2 percent of the ABCP market) failed their cushion tests and liquidated their portfolios (Standard \& Poor's, 2008). Between August 2007 and July 2008, 27 ABCP conduits with business plans that relied, at least in part, on internal liquidity exited the market (Moody's, 2009).

Figure 7 illustrates the boom and bust in the ABCP market since 2001. Until 2005, the total amount of CP outstanding was relatively stable. Between early 2005 and the summer of 2007, the amount outstanding doubled, reaching a peak of $\$ 1.2$ trillion in July 2007. As the ABCP market collapsed, some conduits were unable to roll over their paper, resulting in defaults (Keogh, 2007). Investors became increasingly worried that banks, which provided liquidity facilities to the conduits, would be unable to support them (Mollenkamp, 2007). Covitz, Liang, and Suarez (2009) explain how ABCP programs experienced a series of "runs" between August and December 2007. Many runs were directly linked to the credit and liquidity exposures of individual programs. However, the authors provide evidence that the ABCP market was subject to a panic reminiscent of the banking

\footnotetext{
17 The term "shadow banking system" refers to those non-bank institutions, such as ABCP conduits, that provide funds to businesses.
} 


\section{Figure 7}

\section{Average Monthly ABCP Issuance and Outstanding}

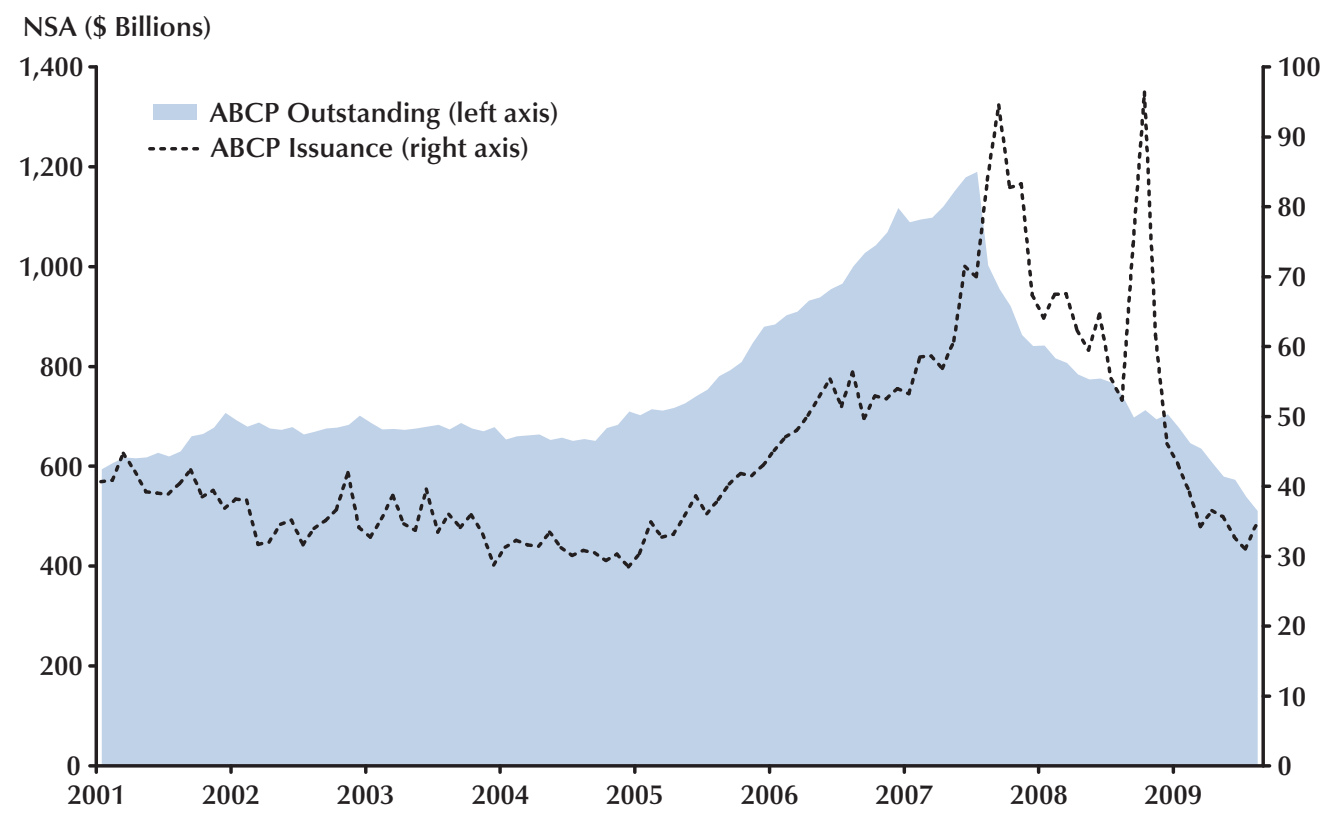

NOTE: *Issuance is only AA rated.

SOURCE: Federal Reserve Board, Volume Statistics for Commercial Paper Issuance.

panics during the Great Depression, in which runs on some programs were not even related to program fundamentals. Broad-based investor concerns that sponsoring banks would be unable to meet their commitments if numerous programs required support at the same time caused extensive withdrawals. Startled investors began to shift their holdings from MMMFs invested in ABCP toward MMMFs invested solely in Treasuries (Figure 8).

Difficulties increased during $2008 .{ }^{18} \mathrm{CP}$ outstanding in December 2008 was $\$ 125$ billion lower than it was a year earlier, with ABCP paper accounting for half that decrease ( $\$ 64$ billion). At year-end 2008, the amount of outstanding ABCP paper was approximately the same as at year-end 2005. Because much of the intervening

\footnotetext{
${ }^{18}$ This section draws heavily on Moody's Investors Service report, “ABCP 2008 Year in Review and 2009 Outlook," February 10, 2009. For additional details see Fitch Ratings (2008a,b, 2009).
}

increase in ABCP paper was mortgage related, the decrease was not unexpected as the housing market cooled. Moody's (2009) reports that the number of ABCP programs declined to 244 from 265, writing that the ABCP market "is returning to one of primarily bank-sponsored multi-seller programs, much as it was a decade ago." Moody's (2009) reports taking rating actions (that is, reducing or reconsidering ratings) on seven ABCP programs during 2008; in all but one case, the action reflected a weakening of an underlying support party (that is, the liquidity or credit enhancer, usually a bank). Advisers to ABCP conduits struggled to sustain their outstanding issues; one ABCP program defaulted because of decreases in the prices of its assets. On occasion, advisers to ABCP conduits shouldered the responsibility for offsetting asset losses: Nine program advisers declared their intent to financially support their affiliated ABCP programs. Many other advisers provided 
Figure 8

\section{Asset Holdings of Taxable Money Market Mutual Funds}

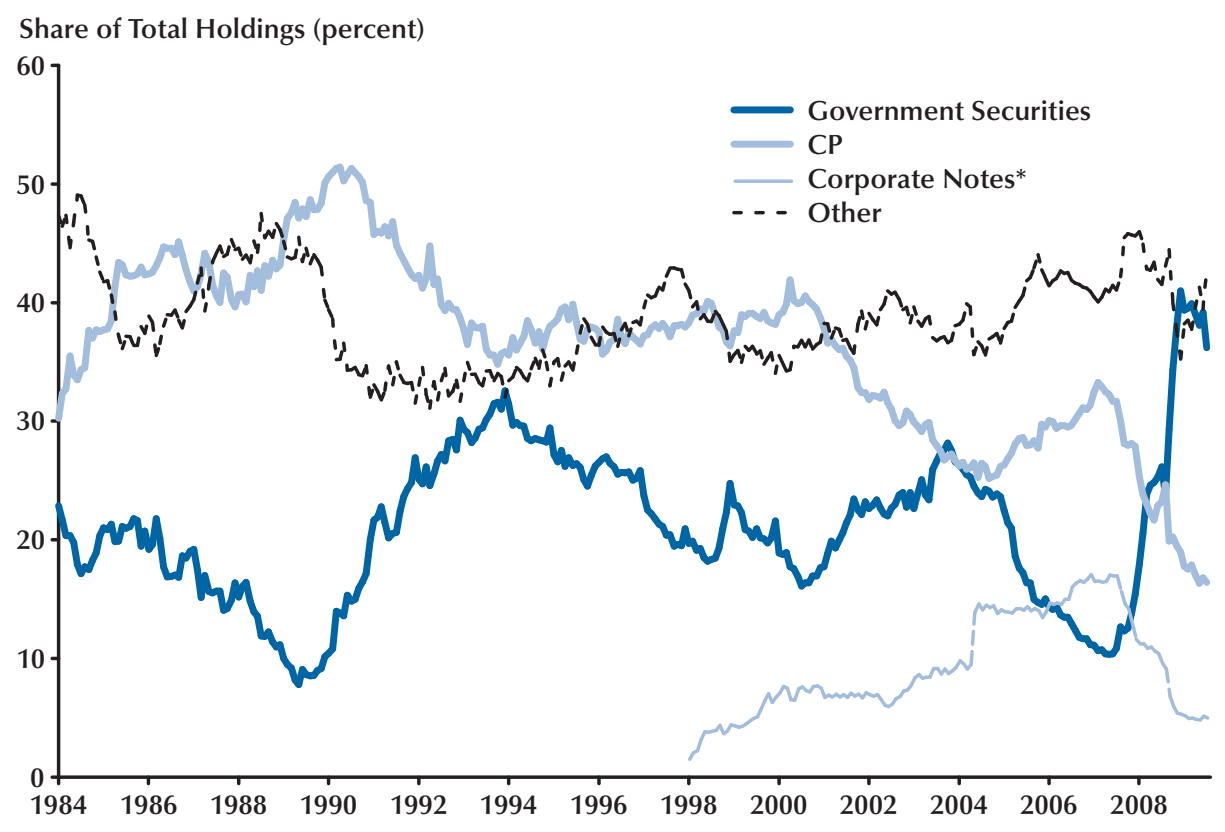

NOTE: *Prior to 1998 Corporate Notes are included in the Other category.

SOURCE: Investment Company Institute.

support for individual assets or purchased assets from the conduit to maintain the conduit's credit quality.

The Lehman Brothers bankruptcy on September 15, 2008, was a major disruption to the CP market. During the months prior to bankruptcy, investors had faced a difficult choice: Sell Lehman's paper at a loss on the rumor of failure, or wait and pray for the rescue of Lehman. Lehman's failure brought immediate stress on the CP market. The following day, at 11 a.m., the $\$ 62$ billion Reserve Primary Fund "broke the buck" (that is, its net asset value fell below $\$ 0.995$ per nominal share) by writing its Lehman investments (with face value of $\$ 785$ million) down to 80 cents per share; at 4 p.m., when it wrote the investments down to zero, the fund's net asset value per share reportedly fell to 97 cents and the fund restricted redemptions (Henriques, 2008). Prior to the Reserve Fund actions, it had been 14 years since investors in MMMFs had experienced a loss; in that case, investors were paid 96 cents per share at liquidation.

Investors in institution-type MMMFs, including corporate cash managers, often use the funds in a manner similar to bank deposits and withdraw the funds on short notice. Losses, of course, are undesired-but a suspension of redemptions is intolerable. At that point, the issue became a crisis of liquidity. Reacting to redemption restrictions, investors shifted more than $\$ 400$ billion from "prime" money funds (invested in CP and other instruments) to money funds invested in Treasuries. Shares in prime funds dropped from $\$ 1.3$ trillion on September 9 to $\$ 864$ billion on October 7, while government-only institutiontype funds increased by more than $\$ 350$ billion (Moody's, 2009). The portfolio reallocation in MMMFs is portrayed in Figure 8. In July 2007, approximately 11 percent of MMMFs portfolios were composed of government securities (i.e., Treasury bills); by January 2009, an average of 


\section{Figure 9}

\section{Selected Overnight Interest Rates}

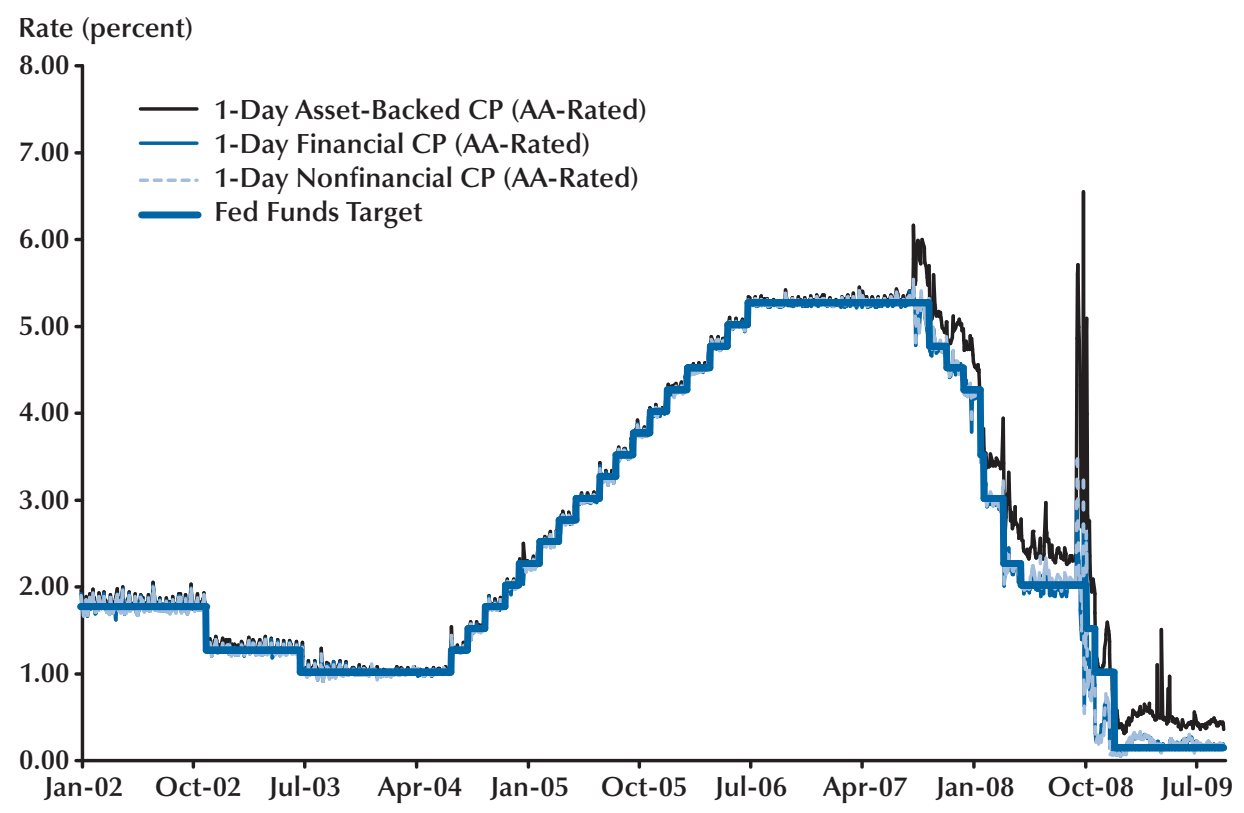

SOURCE: Federal Reserve Board, Table H.15.

40 percent of a fund's portfolio was made up of government securities. At the same time, the share of CP fell from roughly 32 percent to under 20 percent. Retail-type money funds, held primarily by households but also by smaller businesses, were little affected. Quickly, however, MMMFs that were invested in mortgage-related assets came under pressure. Assistance came from banks and fund managers-published reports said more than $\$ 10$ billion was pledged. Nevertheless, the demand for CP fell. Issuance dropped, and brokers and dealers were forced to retain elevated inventories; at the end of 2008's third quarter, dealers held $\$ 154$ billion of ABCP for sale, 78 percent more than a year earlier. ${ }^{19}$ It became difficult to place ABCP for terms longer than overnight; overnight issuance increased from approximately 60 percent of the total to as much as 90 percent. Federal Reserve Board data show,

\footnotetext{
${ }^{19}$ These increases were short-lived. By the fourth quarter of 2008 , brokers in dealers were able to shed roughly 60 percent of their holdings.
}

however, that total issuance decreased littlethe effect of heightened uncertainty was reflected in investors' unwillingness to commit liquid funds for more than one day at a time. Hence, the crisis was primarily one of liquidity- - If I lend today but need to borrow tomorrow, will anyone then lend to me?"-rather than of heightened default risk.

The degree of stress in the ABCP market is reflected in short-term funding rates, all of which increased sharply mid-September, both in absolute level and relative to overnight federal funds (Figure 9). In normal times, CP yields (especially on ABCP) only slightly exceed those on comparable Treasuries. Yet, two prominent spikes are evident in the ABCP rate: late-August to earlySeptember 2007, when mortgage-related writedowns began, and the most prominent in September 2008. A large factor in the September 2008 spike was the scramble by CP issuers for funds when MMMF demand for CP collapsed (Moody's, 2009). 
Figure 10

\section{Federal Reserve Assets (EOP, Wednesday)}

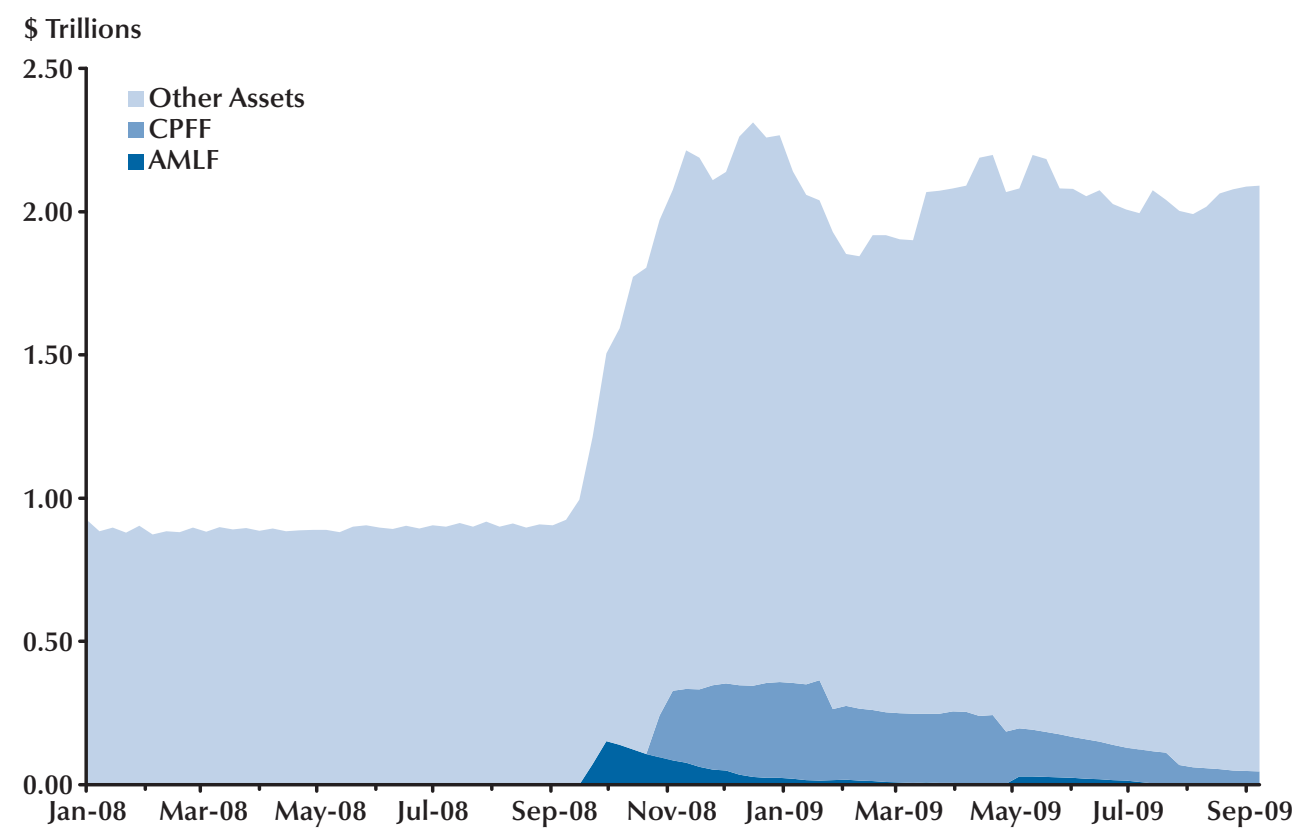

SOURCE: Federal Reserve Board, H.4.1 Table 9.

\section{Recent Treasury and Federal Reserve Programs}

Following mid-September 2008 market disruptions, the Treasury and Federal Reserve introduced programs to enhance liquidity in two ways: (i) by reducing extension risk, that is, the risk that an investor will not repay maturing CP in a timely fashion, either by rolling the paper or bank borrowing; and (ii) by reducing the risk of suspension of redemptions at MMMFs that hold CP. The Treasury, in an effort to assure investors that future suspension of redemptions would not occur, offered insurance for the value of MMMF shares held as of September 18 at funds choosing to participate in its program. ${ }^{20}$ The Federal Reserve introduced three programs with varied objectives, including assuring money fund managers that their CP could be sold quickly if necessary and providing a funding facility that issuers

${ }^{20}$ See U.S. Department of the Treasury (2008) for additional details. of highly rated paper could use as a backstop if rollover failed.

The assets on the Fed's balance sheet are shown in Figure 10. In response to the financial crisis the Fed created numerous lending programs, causing its total assets to increase from under $\$ 1$ trillion to over $\$ 2$ trillion. ${ }^{21}$ The two dark-blue areas represent the assets held by two programs focused on the CP market: the Commercial Paper Funding Facility (CPFF) and the Asset-Backed Commercial Paper Money Market Fund Liquidity Facility (AMLF). Roughly 15 percent of the Fed's assets were acquired through these programs. By comparison, less than 1 percent of the Fed's assets were acquired from Bear Stearns or loans to American International Group (AIG). We review each of these programs below.

Money Market Investor Funding Facility. This program was authorized by the Federal

\footnotetext{
${ }^{21}$ See Gavin (2009) and Gascon (2009) for discussion of other Fed lending programs and their impact on the Fed's balance sheet.
} 
Reserve Board on October 21, 2008, under the provisions of Section 13(3) of the Federal Reserve Act. ${ }^{22}$ The Board describes the program as allowing the Federal Reserve Bank of New York to provide credit to "a series of special purpose vehicles" established "by the private sector" to purchase from eligible investors "certain highly rated, short-term instruments, including certificates of deposit, bank notes, and CP.” Essentially, the SPVs would be authorized to purchase bank debt or CP forcibly sold into the market as a result of a run on a bank or money fund. This program had no activity and expired on October 30, 2009.

Asset-Backed Commercial Paper Money Market Mutual Fund Liquidity Facility. Created on September 19, 2008, the AMLF essentially allows money market funds indirect access to the Federal Reserve discount window via a depository financial institution. The Federal Reserve Board describes this facility as follows:

$[\mathrm{AMLF}]$ is a lending facility that provides funding to U.S. depository institutions and bank holding companies to finance their purchases of high-quality...ABCP from money market mutual funds under certain conditions. The program is intended to assist money funds that hold such paper in meeting demands for redemptions by investors and to foster liquidity in the ABCP market and money markets more generally.

Because money funds themselves are not eligible to borrow at the discount window, to borrow under AMLF they first must sell ABCP to an eligible depository institution. Similar to other programs that seek to assure investors that a suspension of redemptions will not occur in the future, only ABCP owned prior to the AMLF's inception is eligible. Assets of the AMLF initially expanded rapidly, reaching a maximum of $\$ 152$ billion in its second week (the AMLF has the option to resell the paper or hold it until maturity). Since that time, the program's assets have decreased at an

\footnotetext{
${ }^{22}$ Section 13(3) allows the Federal Reserve Banks, under certain conditions and with specified approval of the Board of Governors, to lend to almost any borrower via the discounting of assets. Section 13(3) does not permit direct lending; rather, the funding is supplied via the borrower discounting assets to the Federal Reserve. Hence, using a SPV as the borrower is convenient.
}

average weekly rate of 11 percent. In the week ending April 1, 2009, the AMLF held just over $\$ 6$ billion in assets.

On June 25, 2009, the authorization of the AMLF was extended through February 1, 2010, although with additional administrative criteria to ensure the program is used for its intended purpose of a temporary liquidity backstop.

Commercial Paper Funding Facility. The events of mid-September 2008 made money market investors (who prize liquidity) hesitant to purchase assets with maturities longer than a single day. In normal times, approximately 5 to 10 percent of daily CP issuance is 91-day maturity, and represents 20 to 25 percent of all outstanding paper. In mid-September, 91-day issuance fell to near zero. On Friday, September 12, for example, 60 percent of issuance was 1- to 4-day maturity; by Wednesday, September 17, 87 percent was 1- to 4-day maturity. On October 7, 2008, the Federal Reserve announced the creation of the CPFF to support longer-maturity paper. The CPFF's structure is similar to the Money Market Investor Funding Facility: An SPV purchases 3month corporate unsecured and asset-backed A1/P1-rated CP using funds provided by the Federal Reserve Bank of New York. ${ }^{23}$ The paper is held to maturity. Similar to other CP market support programs, the program is linked to the events of mid-September 2008: The maximum amount an issuer can sell to the CPFF is the maximum amount the issuer had outstanding between January 1 and August 31, 2008, and the CPFF will not purchase from issuers who were inactive prior to its inception. The first purchases by the CPFF occurred on October 27, 2008. It was originally scheduled to purchase paper through on October 30, 2009, but was extended through February 1, 2010, in order to ensure the access of U.S. businesses to short-term funding. However, the interest rates of the CPFF have become increasingly unattractive to many borrowers.

\footnotetext{
${ }^{23}$ The details are more complex than summarized here. Technically, the facility purchases newly issued paper with maturity of 81 days or more. Pricing also is complex, with surcharges of 100 to 300 basis points. Each participating company must also pay a registration fee to use the CPFF. For details, see Federal Reserve Bank of New York (2009b).
} 
Figure 11

\section{CPFF Share of Purchases and Outstanding}

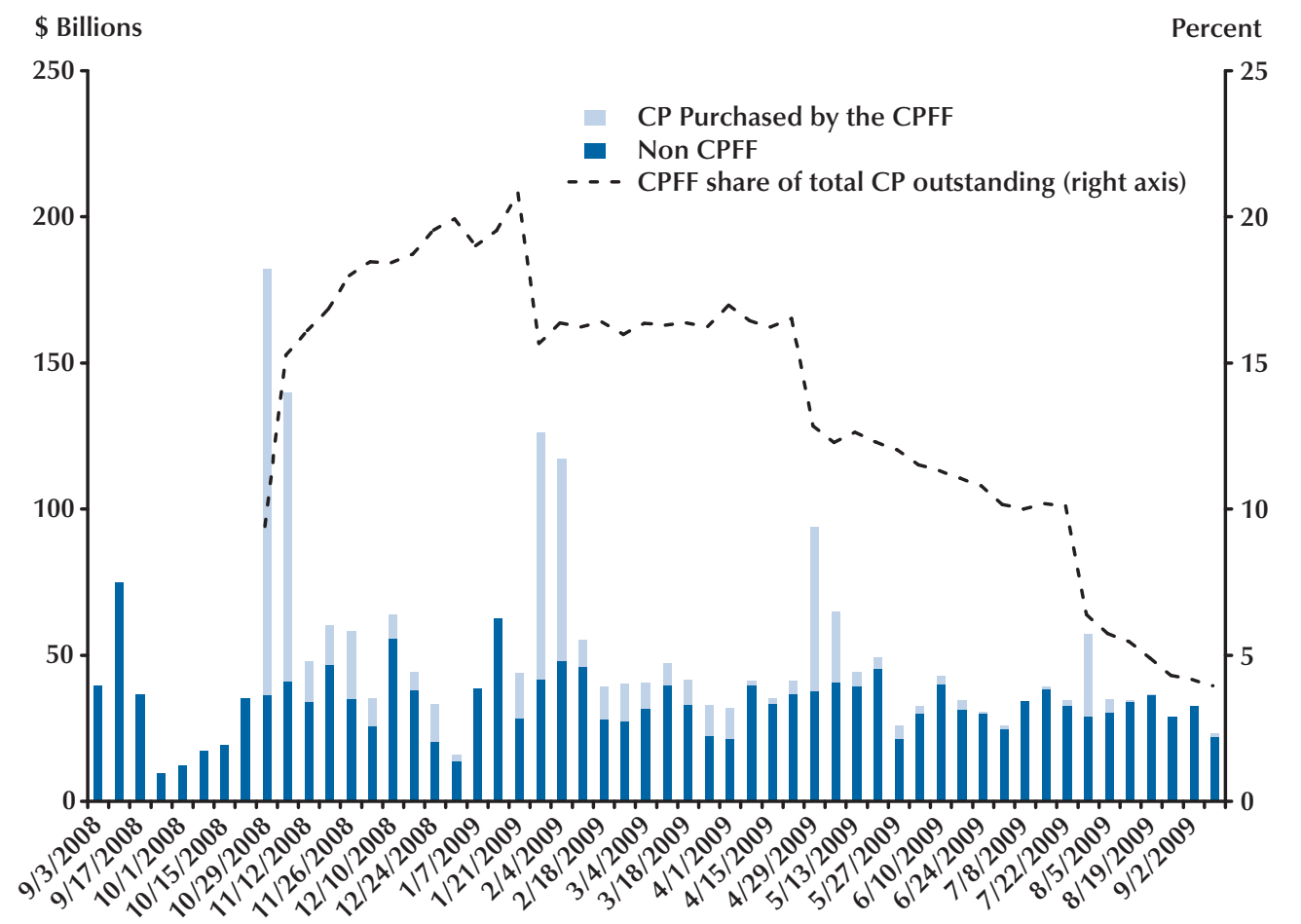

SOURCE: FRB, H.4.1 Table 1; Federal Reserve Bank of New York.

The CPFF has been the most active of the Federal Reserve's three support programs for the CP market and has been cited by Chairman Bernanke (2009) and others as a highly successful market support activity. Hence, its history is worthy of closer examination.

Figure 11 shows the weekly issuance of 3month CP (rated A1/P1 and A2/P2), between September 2008 and February 2009. Issuance decreased sharply during September 2008, but increased steadily during October. During its first two weeks, the CPFF purchased the overwhelming majority of all newly issued eligible 3-month CP. One likely reason for such large volume was the wish by corporations to lock in year-end financing; daily data show that issuance jumped on October 27-29, the first days of purchase by the CPFF. For all weeks thereafter-until the week of January 28, 2009, when the initially purchased 91-day paper matured-relatively little CP was purchased by the CPFF. The second burst of CPFF activity occurred the weeks of January 28 and February 4, when paper purchased by the CPFF in October rolled over. Later weeks show light activity. When the CPFF was in full swing, it held over 20 percent of all CP outstanding, but fewer and fewer investors continued to roll over their paper with the CPFF; at the time of this writing, the CPFF currently holds less than 5 percent of all CP outstanding. The reason likely reflects a pricing policy designed to urge private sector, not CPFF, funding. Funding via the CPFF is not inexpensive, with pricing set to yield 100 to 300 basis points above the overnight index swap rate. Further, some former CPFF borrowers have turned to the Temporary Liquidity Guarantee Program of the Federal Deposit Insurance Corporation, which guarantees bank debt at far longer maturities. 


\section{Figure 12}

\section{Commercial Paper Issuance}

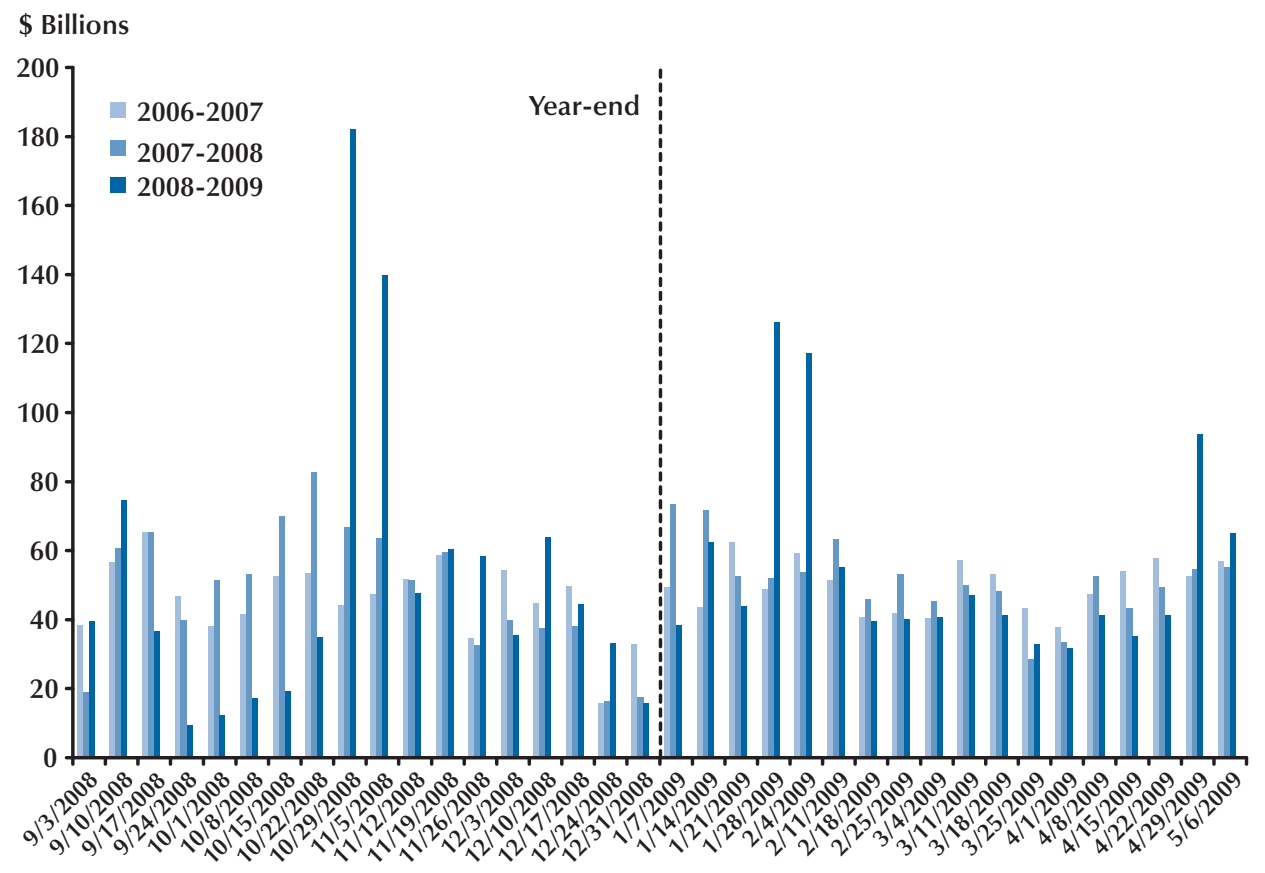

SOURCE: Federal Reserve Board, Volume Statistics for Commercial Paper Issuance.

Figure 12 shows some historical perspective, which compares, side by side, weekly issuance in 2006-07, 2007-08, and 2008-09 of CP with maturity greater than 80 days. The reduction in CP issuance near year-end is quite pronounced. ${ }^{24}$ Although the period mid-September to midOctober 2008 clearly is unusual, issuance appears largely to have recovered by the time of the CPFF's first purchases. Was the CPFF necessary? Would the market have recovered in the absence of the CPFF? Or was the CPFF's presence essential to assure investors that a "purchaser of last resort," similar to the Federal Reserve's discount window, was available to mitigate rollover risk? It is too early to say, as of this writing.

Finally, we note that the CPFF program has been profitable for the Federal Reserve. According to recently issued financial statements (Federal

${ }^{24}$ Musto (1997) and Downing and Oliner (2007) provide a discussion about the year-end effects in the CP market.
Reserve Bank of New York, 2009a), between October 14 and December 31, 2008, the program had a net income of $\$ 1.08$ billion and, as of December 31, 2008, the program had experienced no defaults.

\section{CONCLUSION: THE FUTURE OF COMMERCIAL PAPER}

The CP market and MMMFs have matured together, each complementing the other, and today are the liquid core of the U.S. shadow banking system. Money funds intermediate CP into liquid shares that have many of the characteristics of bank deposits; that is, the money funds provide investors-large or small, retail or institutionala liquid, high-quality, low-risk investment alternative. Simultaneously, money funds purchase CP.

The CP market was originated by firms seeking short-term funds at interest rates and terms 
more favorable than bank loans. The rise of bankadvised, multiseller ABCP conduits during the 1990s extended the market's purpose such that it became focused on asset securitization and risk diffusion, typically with significant off-balancesheet support from the nation's largest commercial banks. Today, the economic role of conduits is similar to the role played by banks. Assets purchased by conduits provide funds to businesses small and large, while conduits' bank advisers seek to monitor the management and performance of those assets' issuers. Simultaneously, the CP issued by conduits provides to investors a liquid, low-risk asset. All of this occurs without the cost and fuss of a banking charter, capital adequacy requirements, or federal deposit insurance.

The rapid growth and large size of the CP market sensitizes it to adverse events, including the bankruptcy of the Penn Central Railroad in 1970 and, more recently, the bankruptcy of Lehman Brothers. The sensitivity is twofold: Issuers of secured paper find it increasingly difficult to roll over their paper, even at shorter maturity and higher cost, and MMMFs and ABCP programs may experience runs. The causes and consequences of these two sensitivities require further research. ${ }^{25}$ Policymakers will also find it necessary to address if and how the regulations will need to be implemented in what is now understood to be a systematically important sector of the U.S. and global economy. ${ }^{26}$ On the other hand, in a low-interest-rate environment, businesses may prefer to secure long-term financing and shift away from CP. To the extent that financial markets currently expect low interest rates to prevail for an extended period, volume in the CP market may be attenuated for some time.

\footnotetext{
${ }^{25}$ We refer readers to Acharya, Gale, and Yorulmazer (2009) for starting points for the discussion on rollover risk, and Covitz, Liang, and Suarez (2009) on runs of ABCP programs.

${ }^{26}$ Acharya, Gale, and Yorulmazer (2009) suggest improving the liquidation value of assets and higher capital requirements as possible solutions. Gatev and Strahan's (2006) results suggest that commercial banks should naturally be well positioned to act as liquidity providers during crises as a "flight to quality" will boost bank reserves, allowing them to meet the demands of their ABCP programs. More obvious remedies would be the permanent establishment of a CPFF-type backstop.
}

\section{REFERENCES}

Acharya, Viral V.; Gale, Douglas M. and Yorulmazer, Tanju. "Rollover Risk and Market Freezes.” Federal Reserve Bank of New York Working paper, February 2009.

Anderson, Richard G. "Bankers' Acceptances: Yesterday's Instrument to Restart Today's Credit Market?" Federal Reserve Bank of St. Louis Economic Synopses, 2009a, No. 5, January 9; http://research.stlouisfed.org/publications/es/09/ ES0905.pdf.

Anderson, Richard G. "Bankers' Acceptances and Unconventional Monetary Policy: FAQs.” Federal Reserve Bank of St. Louis Economic Synopses, 2009b, No. 14, March 18, 2009; http://research.stlouisfed.org/publications/es/09/E S0914.pdf.

Board of Governors of the Federal Reserve System. Banking and Monetary Statistics 1941-1970. Washington, DC: Board of Governors, 1976; http://fraser.stlouisfed.org/publications/bms2/.

Bernanke, Ben S. "The Crisis and the Policy Response." Stamp Lecture, London School of Economics, January 13, 2009; www.federalreserve. gov/newsevents/speech/bernanke20090113a.htm.

Calomiris, Charles W. "Is the Discount Window Necessary? A Penn Central Perspective.” Federal Reserve Bank of St. Louis Review, May/June 1994, 76(3), pp. 31-55.

Cantor, Richard and Rodriques, Anthony P. "Nonbank Lenders and Credit Slowdown," in Studies on Causes and Consequences of the 1989-92 Credit Slowdown. New York: Federal Reserve Bank of New York, February 1994.

Covitz, Daniel; Liang, Nellie and Suarez, Gustavo. "The Evolution of a Financial Crisis: Panic in the Asset Backed Commercial Paper Market.” Federal Reserve Board Finance and Economics Discussion Series: 2009-36, August 18, 2009; www.federalreserve.gov/pubs/feds/2009/200936/ index.html. 
Downing, Chris and Oliner, Stephen. "The Term Structure of Commercial Paper Rates." Journal of Financial Economics, January 2007, 83(1), pp. 59-86.

Federal Reserve Bank of New York. "Commercial Paper Funding Facility LLC: Financial Statements for the Period October 14, 2008 to December 31, 2008, and Independent Auditors Report.” April 2, 2009a; www.newyorkfed.org/aboutthefed/annual/annual08/ CPFFfinstmt2009.pdf.

Federal Reserve Bank of New York. "Commercial Paper Funding Facility: Program Terms and Conditions" (effective June 25, 2009b); www.newyorkfed.org/markets/cpff_terms.html.

Fitch Ratings. "Global Asset-Backed Commercial Paper: 2007 Review and 2008 Outlook." Structured Finance: Asset-Backed Special Report, January 24, 2008.

Fitch Ratings. “The ABCP Paper Trail.” May 2008.

Fitch Ratings. "2009 Outlook for Global ABCP.” Structured Finance: Asset-Backed Special Report, February 12, 2009.

Gascon, Charles S. "Federal Reserve Assets: Understanding the Pieces of the Pie." Federal Reserve Bank of St. Louis Economic Synopses, 2009, No. 13; March 10, 2009; http://research. stlouisfed.org/publications/es/09/ES0913.pdf.

Gatev, Evan and Strahan, Philip E. "Banks' advantage in hedging liquidity risk: theory and evidence from the commercial paper market." Journal of Finance, April 2006, 62(2), 867-91.

Gavin, William T. "More Money: Understanding Recent Changes in the Monetary Base." Federal Reserve Bank of St. Louis Review, March/April 2009, 91(2), pp. 49-59; http://research.stlouisfed.org/ publications/review/09/03/Gavin.pdf.

Hahn, Thomas K. "Commercial Paper” in Timothy Q. Cook and Robert K. Laroche, eds., Instruments of the Money Market. Federal Reserve Bank of Richmond Special Report, 1998, pp. 105-27; www.richmondfed. org/publications/research/special_reports/instruments _of_the_money_market/pdf/chapter_09.pdf.
Henriques, Diana B. "Buck Broken, But Timing May Affect Redemptions." New York Times, November 26, 2008. www.nytimes.com/2008/11/27/business/ 27fund.html?_r=1\&scp=1\&sq=Henriques $\% 20$ and $\%$ 20 November $\% 2027, \% 202008 \%$ 20and $\% 20$ Buck $\%$ 20broken\&st $=$ cse.

Kavanagh, Barbara; Boemio, Thomas R. and Edwards, Gerald A. "Asset-Backed Commercial Paper Programs." Federal Reserve Bulletin, February 1992, 78(2), pp. 107-16.

Keogh, Bryan. "Asset-Backed Commercial Paper Drops Most in 2 Months," Bloomberg, November 8, 2007.

Mollenkamp, Carrick. "Shake-Up At CitigroupCredit Crunch: Commercial-Paper Market Hit by New Investor Anxiety" Wall Street Journal, November 5, 2007.

Moody's Investor Service. "The Fundamentals of Asset-Backed Commercial Paper" Structured Finance: Special Report, Moody's Investors Service, February 3, 2003.

Moody's Investor Service, “ABCP 2008 Year In Review and 2009 Outlook" Structured Finance: Special Report, Moody's Investors Service, February 10, 2009.

Musto, David K., "Portfolio Disclosures and Year-End Price Shifts," Journal of Finance, September 1997, 52(4), pp. 1563-88.

Post, Mitchell A. "The Evolution of the U.S. Commercial Paper Marker Since 1980.” Federal Reserve Bulletin, December 1992, 78(12), pp. 880-91.

Sahn-Bubna, Aparajita. "Commercial Paper Shows Some Stress-Bad Mortgages Weigh On Low-Profile Corner of Short-Term Market." Wall Street Journal, August 8, 2007.

Shen, Pu. "Why Has the Nonfinancial Commercial Paper Market Shrunk Recently?” Federal Reserve Bank of Kansas City, Economic Review, First Quarter 2003.

Standard and Poor's. "The U.S. Asset-Backed Commercial Paper Market May be Down, But It's Not Out." Standard and Poor's Ratings Direct, July 7, 2008. 


\section{Anderson and Gascon}

Stigum, Marcia and Crezcenzi, Anthony. Stigum's Money Market. Fourth edition. New York: McGrawHill, 2007.

United States Department of the Treasury. "Frequently Asked Questions About Treasury's Temporary Guarantee Program for Money Market Funds.” Press Release: HP-1163, September 29, 2008. 